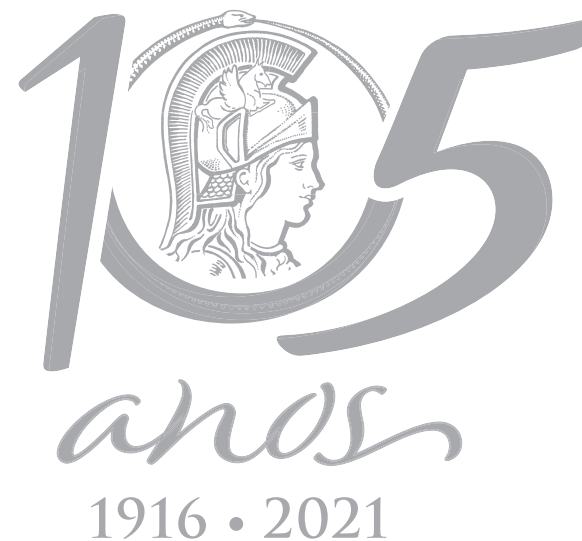

$1916 \cdot 2021$

\title{
Lipid stability of egg and laying performance of Japanese quail feed with extract of guava (Psidium guajava L.)
}

\author{
HELDER F. DE OLIVEIRA, HELOISA HELENA DE C. MELLO, NADJA S.M. LEANDRO, \\ ALESSANDRA G. MASCARENHAS, EDEMILSON C. DA CONCEIÇÃO, EMMANUEL \\ ARNHOLD, MOACIR E. LAGE \& MARIA IZABEL A. SOUZA
}

\begin{abstract}
Two experiments were conducted in order to evaluate the effect of dietary inclusion of guava extract on laying performance and lipid stability of egg of Japanese quails. For the first experiment, 384 Japanese quails with 42 days old were distributed in a completely randomized design with four treatments $\left(0.0 ; 3.0 ; 6.0 ; 9.0\right.$ g. $\mathrm{kg}^{-1}$ guava extract), 6 replicates, and 16 birds/replicate. The experimental period lasted 84 days, divided into 4 cycles of 21 days. The parameters evaluated were: feed consumption, egg production, egg mass, feed conversion ratio, egg weight, and egg internal and external qualities. On the second experiment, 400 eggs from Japanese quails fed with diets containing four levels of guava extract were distributed in a completely randomized design with a $4 \times 4$ factorial arrangement (guava extract levels and storage time: 0, 9, 18, 27 days) with 5 replicates. Analysis of thiobarbituric acid reactive substances was performed on egg yolks. Data were submitted to regression analysis, using $\alpha=0.05$. On the first experiment, the laying performance parameters were not influenced by the inclusion of guava extract in the feed, and eggshell thickness decreased linearly. On the second experiment an interaction was observed between the studied factors, affecting lipid oxidation in egg yolks. At nine days of storage, there was a quadratic effect of levels of dietary guava extract on lipid oxidation of yolk, being observed that using $4.8 \mathrm{~g} . \mathrm{kg}^{-1}$ of guava extract on feed results in less lipid oxidation.
\end{abstract}

Key words: Coturnix japonica, flavonoids, layering, nutrition, phenols, poultry.

\section{INTRODUCTION}

The egg quail production is growing in Brazil whereas the number of quails doubled between 2008 and 2018 (Instituto Brasileiro de Geografia e Estatística 2018). Allied to the productive qualities of quails, the change in global feeding habits noticed throughout the last decade favoured the increase in quail egg consumption. Owing to its nutritive character, quail egg represents a good alternative to improve human nutrient intake, since they constitute a source of proteins, minerals, and vitamins (Souza-Soares \& Siewerdt 2005).

Among other factors, egg quality depends on its storage conditions and on bird nutrition. Changes start to occur right after egg laying, with an egg quality reduction and consequent deterioration (Giampietro-Ganeco et al. 2012). Among many deteriorating phenomena, lipid oxidation is a key issue that must be solved in order to extend the lifetime of oils, fats, and lipid fractions in some foods (Ramalho \& Jorge 2006). Currently, essential plant extracts and oils 
have been used as natural antioxidant sources (Freitas et al. 2013).

In that regard, Brazil is one of the largest guava producers in the world, with an average production of 328.255t (Agrianual 2009). According to Mantovani et al. (2004), during guava processing, after the steps of pulping and washing with chlorinated water, a residue composed mainly of seeds is obtained at a proportion of 4 to $12 \%$ of the total mass of processed fruits.

In addition to its nutritional capacity, the residue obtained from guava processing also shows antioxidant activity, a characteristic correlated with total phenolic content (JiménezEscrig et al. 2001, Melo et al. 2011). According Oliveira et al. (2018), guava byproduct can be used as an alternative antioxidant additive in broiler's diet.

The use of the guava-processing residue on Japanese quails' diet is promising, as long as both the oxidative power on quail egg production and its influence on internal and external egg quality are evaluated. The present study aimed to evaluate the effects of including an antioxidant extract produced from guava processing in the diet of Japanese quails, regarding egg quality and bird performance.

\section{MATERIALS AND METHODS}

Two experiments were conducted between July and November 2015, in Goiânia, GO, Brazil (16 35'33.0"S 49 $\left.16^{\prime} 51.4^{\prime \prime} \mathrm{W}\right)$. All procedures in this study were conducted according to the protocol registration no 075/14 and were approved by the Ethics Committee on Animal Use.

On the first experiment, 384 Japanese quails (Coturnix japonica) aged 42 days were used. The quails weighted $138 \pm 10 \mathrm{~g}$ at the beginning of production phase. Birds were distributed in a completely randomized design with four treatments, six replicates, and 16 birds per experimental unit. The experimental period lasted 84 days, divided into four cycles of 21 days.

The statistical model used was:

$$
y_{i j}=m+t_{i}+e_{i j}
$$

where:

$y_{i j}$ : an observation in treatment $i(i=1,2,3,4)$ and replicate $j(j=1,2,3, \ldots, 6)$;

$m$ : the overall mean;

$t_{\text {: }}$ the fixed effect of treatment $i(i=1,2,3,4)$;

$e_{i j}$ : the random error with mean 0 and variance $\sigma^{2}$.

Treatments consisted of four inclusion levels of guava extract (GE) on diets (0.0; 3.0;

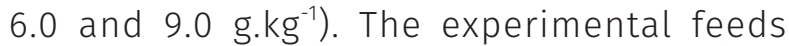
were isonutritive and formulated following the recommendations from Rostagno et al. (2011) (Table I). Starch energy was counted to the total metabolizable energy value.

To obtain the guava extract, residues from the industrial processing, mainly composed of seeds, bark, and pulp remnants, were provided by Industria Predilecta Alimentos LTDA (located in Matão-SP). Residues were dehydrated in a forced air oven at 40으 for 72 hours, after which the material was ground in a knife mill, resulting in a powder that was stored in plastic bags, at room temperature and away from the light. The hydroalcoholic extract was obtained by percolation of the plant material contained in the powder, using $50 \%$ alcohol ( $\mathrm{v} / \mathrm{v}$ ) as solvent. In a percolator containing filter paper and cotton, $2 \mathrm{~kg}$ of plant material and 10 litres of solvent were added, and the material was subjected to maceration for 24 hours.

After percolation started, there was intense dripping until solvent depletion. Care was taken to avoid leaving the powder without solvent, to prevent it from drying out. Afterwards, the 
Table I. Composition and nutricional values of experimental diets containing different levels of inclusion of guava extract (GE).

\begin{tabular}{|c|c|c|c|c|}
\hline \multirow{2}{*}{ Ingredients } & \multicolumn{4}{|c|}{ Treatments (g.kg-1/GE) } \\
\hline & 0.0 & 3.0 & 6.0 & 9.0 \\
\hline Corn & 546.82 & 544.12 & 541.41 & 538.71 \\
\hline Soybean meal & 326.21 & 326.78 & 327.35 & 327.92 \\
\hline Guava extract & 0.00 & 3.00 & 6.00 & 9.00 \\
\hline Starch & 9.00 & 6.00 & 3.00 & 0.00 \\
\hline Soy oil & 14.70 & 16.84 & 18.99 & 21.13 \\
\hline Limestone & 57.80 & 57.80 & 57.80 & 57.79 \\
\hline DL-Methionine & 3.52 & 3.52 & 3.52 & 3.53 \\
\hline L-Lysine HCL & 1.89 & 1.88 & 1.87 & 1.86 \\
\hline L-Tryptophan & 0.06 & 0.06 & 0.06 & 0.06 \\
\hline Premix ${ }^{1}$ & 40.00 & 40.00 & 40.00 & 40.00 \\
\hline TOTAL & 1000.00 & 1000.00 & 1000.00 & 1000.00 \\
\hline \multicolumn{5}{|c|}{ Calculated composition (g.kg-1) } \\
\hline Metabolisable energy $\left(\mathrm{Kcal} / \mathrm{kg}^{-1}\right)$ & $2,800.0$ & $2,800.0$ & $2,800.0$ & $2,800.0$ \\
\hline Sodium & 1.88 & 1.88 & 1.88 & 1.87 \\
\hline Calcium & 30.99 & 30.99 & 30.99 & 30.99 \\
\hline Available phosphorus & 4.06 & 4.06 & 4.06 & 4.05 \\
\hline Crude protein & 199.40 & 199.40 & 199.40 & 199.40 \\
\hline Digestible Lysine & 10.83 & 10.83 & 10.83 & 10.83 \\
\hline Digestible Methionine + Digestible Cystine & 8.88 & 8.88 & 8.88 & 8.88 \\
\hline Digestible Threonine & 6.62 & 6.62 & 6.62 & 6.62 \\
\hline Digestible Tryptophan & 2.27 & 2.27 & 2.27 & 2.27 \\
\hline
\end{tabular}

1 Premix: Provided per kg of product: calcium - 189.65 g; sodium - 37.5 g; phosphorus - 75 g; fluorine - $750 \mathrm{mg}$; retinol - $67.5 \mathrm{mg}$; cholecalciferol - $1.75 \mathrm{mg}$; tocopherol - $1.27 \mathrm{mg}$; menadione - $50 \mathrm{mg}$; thiamine - $82.5 \mathrm{mg}$; riboflavin - $212.5 \mathrm{mg}$; pyridoxine - 125 mg; cobalamin - $0.50 \mathrm{mg}$; pantothenic acid - $375 \mathrm{mg}$; niacin - $875 \mathrm{mg}$; folic acid - $37.5 \mathrm{mg}$; biotin - $5 \mathrm{mg}$; choline - $4.875 \mathrm{mg}$; Cu $225 \mathrm{mg}$ (as CuSO$)_{4}$; $\mathrm{Fe}-1.125 \mathrm{mg}$ (as $\mathrm{FeSO}_{4}$ ); $\mathrm{Mn}-2.500 \mathrm{mg}$ (as $\mathrm{MnSO}_{4}$ ); iodo - $22.5 \mathrm{mg}$ (as Ca( $\left.\left(\mathrm{IO}_{3}\right)_{2}\right) ; \mathrm{Zn}-750 \mathrm{mg}$ (as $\left.\mathrm{ZnSO}\right)_{4}$; $\mathrm{Se}^{-12.5}$ $\mathrm{mg}$ (as $\mathrm{Na}_{2} \mathrm{SeO}_{3}$ ); zinc bacitracin - $550 \mathrm{mg}$; methionine $28.7 \mathrm{~g}$.

liquid obtained from the percolated powder was retrieved in 10 rounds, based on the method adapted from the Formulário de Fitoterápicos da Farmacopeia Brasileira (BRASIL 2011). After percolation, the liquid extract was concentrated by solvent evaporation using a fan at room temperature until a solid content of $3.7 \%$ was obtained. The processing of the concentrated extract was performed on the Laboratory of
Research, Development and Innovation of Bioproducts of the Faculty of Pharmacy of the Federal University of Goiás.

In the standard tannic acid curve, constructed through the absorbance versus concentration ratio, the equation and $R^{2}$ value for the determination of the concentration of total phenols in the extract are expressed (Figure 1). 
Birds were allocated in groups with 24 experimental cages made of galvanized wire, measuring $100 \times 40 \times 16 \mathrm{~cm}$ (length, width, and height, respectively), subdivided into four compartments of $100 \times 40 \times 16 \mathrm{~cm}$ equipped with nipple-type drinkers, trough-type feeders and excreta trays.

Maximum and minimum temperatures during the experimental period were recorded by using a digital thermo hygrometer. The maximum and minimum values recorded were $34.7^{\circ} \mathrm{C}$ and $18.7^{\circ} \mathrm{C}$, respectively. An automated timer was used to control the photoperiod, which consisted of 17 hours/continuous light, with 11 hours of natural light and 6 hours of artificial light. Feed and water were provided freely during the experimental period.

At the end of each 21-day period, feed consumption (g/bird/day), egg production (\%), egg mass $(\mathrm{kg})$, food conversion ratio per egg mass $(\mathrm{kg} / \mathrm{kg})$ and per dozen eggs $(\mathrm{kg} / \mathrm{dz})$ were evaluated. On the last three days of each period, mean egg weight, yolk weight (g), albumen weight (g), albumen diameter ( $\mathrm{mm})$, yolk colour (score 1 to 15), specific gravity, Haugh unit, yolk index, albumen index, albumen, shell and yolk percentages, and yolk and albumen $\mathrm{pH}$ were evaluated in order to assess egg quality.

Eggs were collected once a day and production (\%) was calculated by dividing the total amount of eggs per experimental unit on that period by the number of quails. Feed consumption (g/bird/day) was calculated by the difference between weights of the provided feed and the leftovers on the 1st and 21st days of the cycle, respectively, for each experimental unit. Egg mass was calculated by multiplying the egg production (units) by the mean egg weight (g) per parcel. Food conversion per egg mass was calculated by the ratio between feed consumption and egg production, and the result was multiplied by 12 .

Specific gravity (SG) was determined according to the methods described by Hamilton (1982), where eggs were immersed in saline solutions with densities varying from 1.050 to 1.090 with an interval of 0.005 .

The albumen and yolk heights ( $\mathrm{mm}$ ) were measured with a micrometre. Yolk index was determined by the ratio between yolk height and yolk diameter. Albumen index was determined by the ratio between albumen height and the average of the two measured albumen

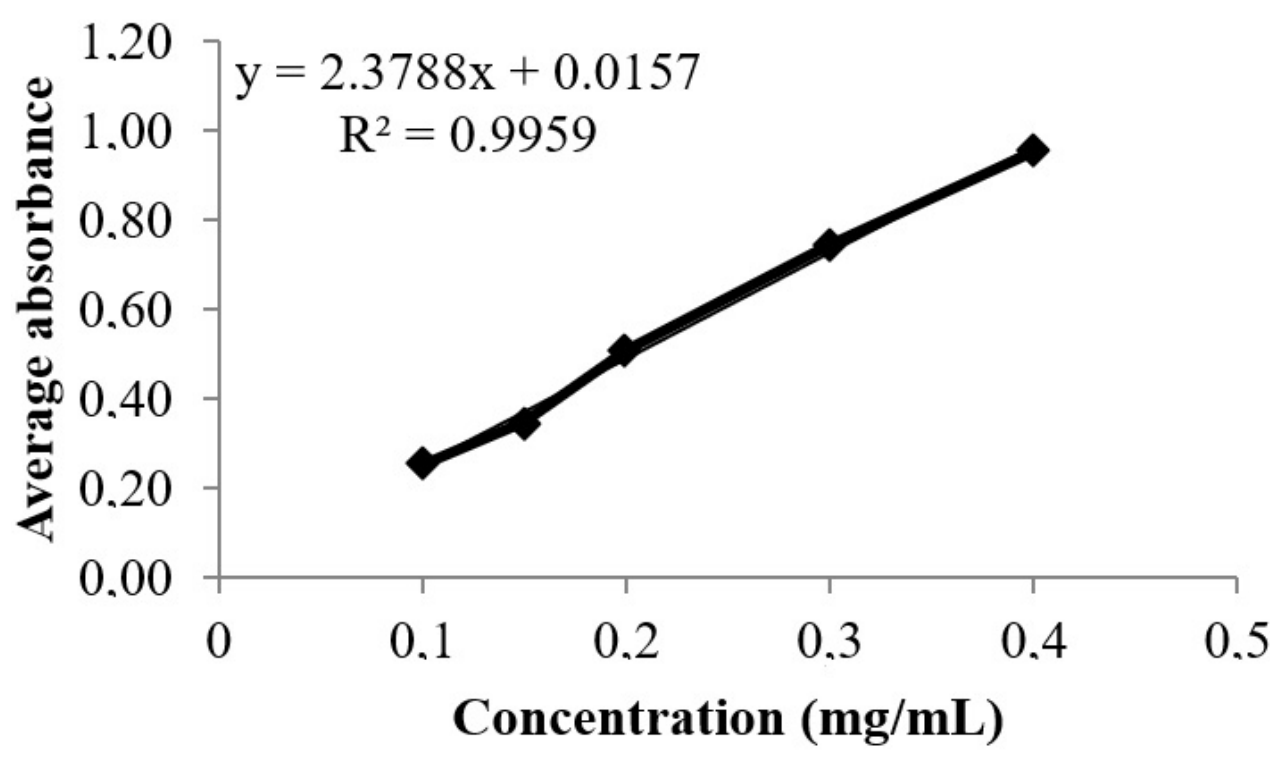

Figure 1. Standard curve for the measurement of total phenols in the concentrated liquid extract of guava. 
diameters. Haugh unit was calculated following the equation: $\mathrm{UH}=100 \times \log \left(\mathrm{H}-1.7 \mathrm{P}^{0.37}+7.57\right)$, where: $\mathrm{UH}=$ Haugh unit; $\mathrm{H}=$ albumen height; $\mathrm{P}=$ egg weight (Silva 2004).

Yolk and albumen diameters were measured with a digital calliper $( \pm 0.01 \mathrm{~mm})$. Albumen diameter was measured in two widths (smaller and larger), obtaining the average between these two values expressed in millimetres $(\mathrm{mm})$ to determine the albumen index.

Yolk colour was determined using a colour fan from Roche ${ }^{\circledR}$. Yolk and albumen $\mathrm{pH}$ were determined with a bench $\mathrm{pH}$ meter. Composed samples were made out of four albumens and four yolks.

Egg shells were washed and dried at room temperature for 72 hours, after which they were weighted. Shell thickness was measured with a digital calliper in two points at the middletransversal area of the shell, from which an average measure expressed in millimetres $(\mathrm{mm})$ was obtained for statistical analysis.

Albumen weight was determined through the equation: $\mathrm{AW}=\mathrm{EW}-\mathrm{YW}-\mathrm{SW}$, where $\mathrm{AW}$ = albumen weight; EW = egg weight; YW = yolk weight; SW = shell weight. Percentages of yolk, shell and albumen were obtained through the relationship: (component weight/egg weight multiplied) $\times 100$.

The data were presented as a pool of the results of each cycle.

At the end of the first experiment, 400 eggs from Japanese quails fed experimental diets containing four different levels of guava extract were used to perform the second experiment. A completely randomized experimental design with a factorial arrangement $4 \times 4$ was used, with four levels of guava extract inclusion (0.0; 3.0; 6.0 and $9.0 \mathrm{~g} . \mathrm{kg}^{-1}$ ) and four storage times (0; 9; 18 and 27 days), totalling 16 treatments with five replicates and five eggs per replicate.

The statistical model used was:

$$
y_{i j k}=m+a_{i}+b_{j}+(a b)_{i j}+e_{i j k}
$$

where:

$y_{i j k}$ : an observation in level $\mathrm{i}$ of factor a $(i=1,2,3,4)$, level $j$ of factor $b(j=1,2,3,4)$ in repetition $k$ $(k=1,2, \ldots, 5)$;

$m$ : the overall mean;

$a_{i}$ : the fixed effect of level $i$ of factor a $(i=1,2,3,4)$; $b_{\text {: }}$ : the fixed effect of level $j$ of factor $b(j=1,2,3,4)$; $(a b)_{i j}$ : the effect of the interaction of level $i$ of factor a $(i=1,2,3,4)$ with level $j$ of factor $b(i=1,2,3,4)$; $e_{i j k}$ : the random error with mean 0 and variance $\sigma^{2}$.

Eggs were stored in identified commercial plastic packages and kept at room temperature. Analysis of thiobarbituric acid reactive substances (TBARS) was performed on fresh egg yolks at 9, 18 and 27 days of storage.

The maximum and minimum temperatures were recorded by a digital thermo hygrometer. Maximum and minimum temperatures during

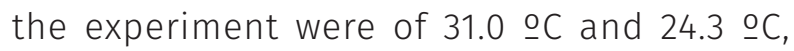
respectively.

At each storage period, five eggs representing an experimental unit were broke. Yolks were separated from the albumen and the yolk pools of each treatment were kept frozen in a Coldlab/CL120-86V freezer at -80 o C for subsequent TBARS analysis. This temperature interrupts processes that degrade the material.

Lipid oxidation was determined by quantifying TBARS, which was measured by spectrophotometry at $538 \mathrm{~nm}$ absorbance and expressed in $\mathrm{mg}$ of malondialdehyde per gram of sample according to the methodology adapted from Vyncke (1970).

For the TBARS analysis, the yolk pools was defrosted for 24 hours in a conventional refrigerator and then homogenized. Two $5 \mathrm{~g}$ samples were taken from each replicate, and $12.5 \mathrm{ml}$ of trichloroacetic acid at $7.5 \%$ were added. Samples were homogenized for one minute in 
an aluminium homogenizer cup equipment. The content was filtered through a qualitative paper filter and $2.5 \mathrm{ml}$ of thiobarbituric acid at $1 \%$ were added to the filtered sample. Samples were submitted to a water bath for 40 minutes and then cooled for 15 minutes at room temperature. Finally, the malondialdehyde and thiobarbituric acid reactive substances contents were determined by spectrophotometry.

Bird performance and egg quality data were evaluated by regression analysis $(\alpha=0.05)$, considering a tendency of $\alpha$ between 0.05 and 0.1 . Data on lipid oxidation were evaluated by ANOVA and regression analysis to levels of dietary guava extract $(\alpha=0.05)$. The $R$ Development software package was used in all analysis.

\section{RESULTS}

Inclusion of the guava extract did not affect $(P>0.05)$ feed consumption, laying percentage, produced egg mass, and feed conversion ratio (Table II). A tendency for linear reduction $(P=0.079)$ could be observed on the conversion per egg mass $(\mathrm{kg} / \mathrm{kg})$, following the increased levels of guava extract in the feed.
Egg quality (egg weight, yolk and shell weight, yolk, shell and albumen percentages) was not influenced ( $P>0.05)$ using guava extract on diets (Table III). There was a tendency of increase of albumen weight according to inclusion of guava extract in diet $(P=0.094)$.

Except for eggshell thickness, differences in internal and external egg qualities (Table IV) were not observed $(P>0.05)$ among the quails fed with different guava extract levels. Eggshell thickness was influenced $(P=0.012)$ by guava extract on feeds and decreased linearly.

There was an interaction $(P<0.05)$ between the studied factors (guava extract levels $x$ eggs storage period) on the yolk lipid oxidation (Table $V$ ). According to the interaction, there was no significant difference $(P>0.05)$ on time 0,18 and 27 days related to the levels of guava extract tested. It is possible to infer that there was no antioxidant effect of the guava extract for fresh eggs, thus no differences in egg quality. At nine days of storage, there was a quadratic effect of levels of dietary guava extract on lipid oxidation of yolk, being observed that using 4.8 g. $\mathrm{kg}^{-1}$ of guava extract on feed results in less lipid oxidation.

Table II. Feed consumption (FC), egg production (EP), egg mass (EM), conversion per egg mass (CEM) and dozens of eggs (CDE) of japanese quails fed diets containing different levels of guava extract.

\begin{tabular}{|c|c|c|c|c|c|}
\hline $\begin{array}{r}\text { LEVELS } \\
\left(\mathrm{g} \cdot \mathrm{kg}^{-1}\right)\end{array}$ & $\begin{array}{c}\text { FC } \\
\text { (g/bird/day) }\end{array}$ & $\begin{array}{l}\text { EP } \\
(\%)\end{array}$ & $\begin{array}{l}\mathrm{EM} \\
(\mathrm{kg})\end{array}$ & $\begin{array}{l}\text { CEM } \\
(\mathrm{kg} / \mathrm{kg})\end{array}$ & $\begin{array}{c}\text { CDE } \\
(\mathrm{kg} / \mathrm{dz})\end{array}$ \\
\hline 0.0 & 26.14 & 96.34 & 3.867 & 2.273 & 0.326 \\
\hline 3.0 & 25.72 & 96.41 & 3.896 & 2.219 & 0.320 \\
\hline 6.0 & 26.16 & 96.61 & 3.996 & 2.202 & 0.325 \\
\hline 9.0 & 26.19 & 96.01 & 3.972 & 2.216 & 0.327 \\
\hline \multicolumn{6}{|c|}{$P$ value } \\
\hline Linear & 0.422 & 0.702 & 0.192 & $0.079^{*}$ & 0.343 \\
\hline Quadratic & 0.313 & 0.636 & 0.502 & 0.172 & 0.235 \\
\hline \multicolumn{6}{|c|}{ SEM } \\
\hline & 0.0002 & 0.7087 & 0.0383 & 0.0242 & 0.0032 \\
\hline
\end{tabular}

${ }^{*} Y=2.2561-0.0627 x ; R^{2}=0.56 ; S E M:$ standard error. 
Table III. Mean egg weight (EW); yolk weight (YW); shell weight (SW); and albumen weight (AW); percentage of yolk, shell and albumen of japanese quail eggs fed with diets containing different levels of guava extract.

\begin{tabular}{|c|c|c|c|c|c|c|c|}
\hline $\begin{array}{l}\text { LEVELS } \\
\left(\mathrm{g} . \mathrm{kg}^{-1}\right)\end{array}$ & $\begin{array}{l}\text { EW } \\
\text { (g) }\end{array}$ & $\begin{array}{l}\text { YW } \\
\text { (g) }\end{array}$ & $\begin{array}{l}\text { SW } \\
\text { (g) }\end{array}$ & $\begin{array}{l}\text { AW } \\
\text { (g) }\end{array}$ & $\begin{array}{c}\text { YOLK } \\
\text { (\%) }\end{array}$ & $\begin{array}{c}\text { SHELL } \\
(\%)\end{array}$ & ALBUMEN (\%) \\
\hline 0.0 & 11.94 & 3.56 & 0.94 & 7.44 & 29.81 & 7.93 & 62.26 \\
\hline 3.0 & 12.03 & 3.64 & 0.95 & 7.44 & 30.25 & 7.91 & 61.84 \\
\hline 6.0 & 12.31 & 3.61 & 0.96 & 7.73 & 29.34 & 7.83 & 62.83 \\
\hline 9.0 & 12.31 & 3.72 & 0.95 & 7.64 & 30.20 & 7.77 & 62.03 \\
\hline \multicolumn{8}{|c|}{$P$ value } \\
\hline Linear & 0.151 & 0.605 & 0.310 & $0.094^{*}$ & 0.271 & 0.751 & 0.228 \\
\hline Quadratic & 0.647 & 0.669 & 0.468 & 0.421 & 0.208 & 0.830 & 0.250 \\
\hline \multicolumn{8}{|c|}{ SEM } \\
\hline & 0.0844 & 0.0308 & 0.0090 & 0.0589 & 0.1622 & 0.0691 & 0.01655 \\
\hline
\end{tabular}

${ }^{*} \mathrm{Y}=7.4280-0.2989 x ; R^{2}=0.57 ;$ SEM: standard error.

Table IV. Egg shell thickness (ST); specific gravity (SG); Haugh unit (HU); yolk color (YC); yolk index (YI); albumen index (AI); pH of yolk and albumen of japanese quail eggs fed diets containing different levels of guava extract.

\begin{tabular}{|c|c|c|c|c|c|c|c|c|}
\hline $\begin{array}{l}\text { LEVELS } \\
\left(\mathrm{g} . \mathrm{kg}^{-1}\right)\end{array}$ & $\begin{array}{c}\text { ST } \\
(\mathrm{mm})\end{array}$ & SG & HU & $\begin{array}{c}\text { YC } \\
\text { (1 to } 15)\end{array}$ & YI & Al & $\begin{array}{c}\text { pH } \\
\text { YOLK }\end{array}$ & $\begin{array}{c}\mathrm{pH} \\
\text { ALBUMEN }\end{array}$ \\
\hline 0.0 & 0.20 & 1.069 & 91.64 & 4.17 & 0.46 & 0.12 & 5.98 & 8.64 \\
\hline 3.0 & 0.19 & 1.069 & 91.77 & 4.12 & 0.46 & 0.12 & 6.00 & 8.62 \\
\hline 6.0 & 0.18 & 1.069 & 90.94 & 4.39 & 0.45 & 0.12 & 5.95 & 8.59 \\
\hline 9.0 & 0.18 & 1.068 & 90.98 & 4.73 & 0.45 & 0.12 & 6.00 & 8.61 \\
\hline \multicolumn{9}{|c|}{ P value } \\
\hline Linear & $0.012^{*}$ & 0.791 & 0.759 & 0.445 & 0.205 & 0.623 & 0.601 & 0.596 \\
\hline Quadratic & 0.133 & 0.555 & 0.917 & 0.183 & 0.488 & 0.790 & 0.595 & 0.701 \\
\hline \multicolumn{9}{|c|}{ SEM } \\
\hline & 0.0027 & 0.0006 & 0.4337 & 0.0749 & 0.0047 & 0.0031 & 0.0308 & 0.0514 \\
\hline
\end{tabular}

\section{DISCUSSION}

The feed consumption was not different among the treatments studied, since feeds were isonutritive and isoenergetic, and consequently no alteration on the productive performance occurred. This result was similar to the one found by Freitas et al. (2013), who studied the inclusion of mango extract on laying hens feed, with similar antioxidant function and no found differences regarding performance variables. 
According Mello et al. (2018) the use of 0.3\% inclusion of guava extract, contained ellagic acid in layer quail diets enhance the intestinal development of the neonate quail. So, it was expected that antioxidant substances on guava extract would improve the performance of quail, possibly by increasing nutrient absorption by improving poultries intestinal health, however, it was not observed.

Eggs internal components are produced by hormonal stimuli. Considering those stimuli are mechanisms activated by hormonal pathways, guava extract may have had no effect on the quantitative increase of these components, and consequently no effect on the increase of mean egg weight. Additionally, the feed consumption was not different according to use of guava extract in diets, resulting in similar egg weight and egg internal components, although it has been observed a tendency to increase the albumen weight. Wang et al. (2018) verified that dietary supplementation of tea polyphenols, a natural antioxidant, affect the albumen quality of laying hens. The authors related that the effects may be associated with improvement of the magnum health status and ovomucin composition. Since the guava extract is rich in phenols compounds, it could have a similar effect to tea polyphenols.
Zhao et al. (2011) observed no difference on egg weight of commercial laying hens fed diets containing ginger powder, an antioxidant additive rich in polyphenolic compounds such as the guava extract. Freitas et al. (2013) also verified no difference on yolk, shell and albumen weights of commercial laying hens fed diets containing extracts from mango seed and skin, which are fractions rich in total phenolic compounds (Huber et al. 2012). These are bioactive compounds with great antioxidant potential, similar to the guava extract used on Japanese quail feeds in the present study.

The eggshell thickness is related to laying hens age, weight, and egg size (Oliveira \& Oliveira 2013). Normally, there is a decrease in eggshell percentage and thickness as the bird produces larger eggs. In this study, it was observed that the guava extract results in decrease of eggshell thickness. The excess of reactive oxygen species (ROS) may inhibit osteoblast differentiation and proliferation and stimulating osteoclastogenesis (Li et al. 2009). Therefore, the use of an antioxidant could reduce the ROS production and improve the bone mineralization. Some authors have been related the protective effect on bone of lycopene, that is also a natural antioxidant. Liang et al. (2012) concluded that lycopene treatment can inhibit bone loss and

Table V. Lipid oxidation means (TBARS values) of egg yolks from japanese quails fed diets containing different levels of guava extract stored at $0,9,18$ and 27 days expressed as $\mathrm{mg} / \mathrm{MDA} / \mathrm{kg}$.

\begin{tabular}{|c|c|c|c|c|c|c|c|c|c|c|}
\hline \multirow{2}{*}{$\begin{array}{l}\text { PERIOD } \\
\text { (days) }\end{array}$} & \multicolumn{4}{|c|}{$\begin{array}{l}\text { LEVELS } \\
\left(\mathrm{g} \cdot \mathrm{kg}^{-1}\right)\end{array}$} & \multicolumn{3}{|c|}{$\begin{array}{l}\text { ANOVA } \\
P \text { value }\end{array}$} & \multirow[t]{2}{*}{$\mathrm{L}^{4}$} & \multirow[t]{2}{*}{$Q^{5}$} & \multirow[t]{2}{*}{ SEM $^{6}$} \\
\hline & 0.0 & 3.0 & 6.0 & 9.0 & $\mathbf{T}^{1}$ & $D^{2}$ & $T^{*} D^{3}$ & & & \\
\hline 0 & 1.780 & 1.8250 & 1.6824 & 1.7447 & \multirow{4}{*}{0.2189} & \multirow{4}{*}{0.0188} & \multirow{4}{*}{0.0244} & 0.5191 & 0.4336 & \multirow{4}{*}{0.069} \\
\hline 9 & 1.8513 & 1.4934 & 1.7171 & 1.7171 & & & & 0.012 & $0.0136^{*}$ & \\
\hline 18 & 1.6908 & 1.6465 & 1.6809 & 1.5806 & & & & 0.8745 & 0.5718 & \\
\hline 27 & 1.7816 & 1.8171 & 1.6579 & 1.9276 & & & & 0.1525 & 0.0803 & \\
\hline
\end{tabular}

${ }^{1} \mathrm{~T}=$ treatment; ${ }^{2} \mathrm{D}=$ period; ${ }^{3} \mathrm{~T}^{*} \mathrm{D}=$ interaction treatment and period; ${ }^{4} \mathrm{~L}=\mathrm{Linear} ;{ }^{5} \mathrm{Quadratic} ;{ }^{6} \mathrm{SEM}=$ standard error.

*Y $=1.8109-0.9539 x+0.9939 x^{2} ; \hat{Y}=4.8 R^{2}=0.23$ 
increase bone strength in rats. However, it could result in priorization of bone formation in detriment of eggshell development, that results in thinner eggshell when an antioxidant is used in diets.

No significant differences were observed on specific gravity. However, these values are consistent with the ones found by Costa et al. (2008) and are slightly smaller than the ones observed by Móri et al. (2005), both working with laying Japanese quails.

The Haugh unit (HU) did not differ with the inclusion of guava extract in the feed, because no effects were observed in egg weight and albumen height. It is known that albumen height tends to suffer alterations after laying, and the analysis was performed on fresh eggs.

The HU is directly related to egg weight and albumen height. It is used as an indicator of egg quality, since as the egg deteriorates and albumen spreads, a smaller value for that index is obtained (Harder et al. 2008).

Although the guava fruit has significant levels of total carotenoids, like lycopene, an element with pigmenting and antioxidant effects (Fernandes et al. 2007, Oliveira et al. 2011), the observed values for yolk colour did not present any significant differences. Still, despite yolk colour being a criterion to evaluate quality for the consumer or the industry, quail eggs are usually consumed cooked and whole, unlike chicken eggs that are submitted to cooking, frying or processing by the food industry. Therefore, quail yolk colour is an attribute of secondary importance or low relevance (Moura et al. 2010).

The quality of eggs internal components can be evaluated by the yolk and albumen indexes. Albumen index is calculated by dividing its height by its mean diameter. Thus, a higher value for albumen height yields a higher index and a higher-quality egg. Normally, the results vary between 0.09 and 0.12 for that index. Similarly, yolk index is calculated by dividing its height by its diameter, and results ranging from 0.39 to 0.45 indicate eggs with good internal quality (Oliveira \& Oliveira 2013). The results observed in present study demonstrate that the analysed eggs are inside the optimum range for their respective indexes, thus attesting good quality of their internal components. Yolk and albumen $\mathrm{pH}$ values did not differ statistically, but they are consistent with the values observed by Oliveira \& Oliveira (2013) for fresh eggs, similar to those observed by Figueiredo et al. (2011) for albumen $\mathrm{pH}$ of commercial laying hens eggs.

At nine days of storage, was observed that the use of $4.8 \mathrm{~g} . \mathrm{kg}^{-1}$ of guava extract, the TBARS value was reduced in egg yolks. These results corroborate those of Freitas et al. (2013), who observed that it is possible to delay lipid oxidation of commercial laying hens eggs stored for up to 60 days, by using an ethanol extract rich in polyphenolic compounds with antioxidant potential produced from mango seeds. Zhao et al. (2011), using ginger powder in commercial laying hens, observed that adding 10 to $15{\mathrm{~g} . \mathrm{kg}^{-1}}^{-1}$ of ginger powder to diets improved oxidative stability on egg yolk. Roriz (2014) supplemented feeds of producing European quails with vitamin C associated with two types of plant oil (soybean and/or sunflower) and observed that it caused no effect on lipid oxidation of raw or cooked eggs stored for up to 28 days. Radwan et al. (2008) observed positive effects on oxidative stability of commercial laying hens egg yolks in laying phase by adding $1 \%$ oregano or rosemary, or 0.5 and $1.0 \%$ turmeric to the feeds.

The eggs that were not storage did not show difference in lipid oxidation according to the levels of dietary guava extract, indicating that the antioxidant effect was not effective to improve the egg quality at laying. Similarly, at 18 and 27 days of storage, the lipid oxidation 
of yolk was not affected using guava extract in diets. So, it is possible that for long periods of storage, the antioxidant effect of guava extract in levels studied was not enough to improve the lipid oxidation of eggs.

Although there were no significant results on Japanese quail performance in laying phase and on the eggs quality with the inclusion of guava extract, a promising antioxidant additive for Japanese quails feeds in production phase was shown, based on the lipid oxidation (TBARS) results obtained with the eggs stored for nine days. Further studies are necessary to define the economic viability and the possibility of using the extract in large scale.

In summary, the addition of $4.8 \mathrm{~g} \mathrm{~kg}^{-1}$ guava extract in diets of Japanese quails in production phase reduces the lipid oxidation of egg yolks stored for nine days. Furthermore, it does not affect the productive performance and the internal and external characteristics of fresh egg, except for shell thickness, which decreased linearly.

\section{CONCLUSIONS}

The addition of $4.8 \mathrm{~g} \mathrm{~kg}^{-1}$ guava extract in diets of Japanese quails in production phase reduces the lipid oxidation of egg yolks stored for nine days

\section{Acknowledgments}

The authors thank Indústria Predilecta Alimentos LTDA for providing the guava residue used to make the extract. This study was financed in part by the Coordenação de Aperfeiçoamento de Pessoal de Nivel Superior - Brazil (CAPES) - Finance Code 001.

\section{REFERENCES}

AgriAnUAL $\left(14^{\text {th }}\right)$. 2009. Anuário estatístico da Agricultura Brasileira. São Paulo: FNP Consultoria \& Comércio, 497 p.
BRASIL. 2011. Agência Nacional de Vigilância Sanitária. Formulário de Fitoterápicos da Farmacopeia Brasileira/ Agência Nacional de Vigilância Sanitária 2011; [access date: jan 2, 2016]. URL: http://www.anvisa.gov.br/hotsite/ farmacopeiabrasileira/conteudo/Formulario_de_ Fitoterapicos_da_Farmacopeia_Brasileira.pdf.

COSTA FGP, RODRIGUES VP, GOULART CC, LIMA NETO R, SOUZA JG \& SILVA JHV. 2008. Exigências de lisina digestivel para codornas japonesas na fase de postura. R Bras Zootec 37: 2136-2140.

FERNANDES AG, MAIA GA, SOUSA PHM, COSTA JMC, FIGUEIREDO RW \& PRADO GM. 2007. Comparação dos teores em vitamina C, carotenoides totais, antocianinas totais e fenólicos totais do suco tropical de goiaba nas diferentes etapas de produção e influência da armazenagem. Alim Nutr 18: 431-438.

FIGUEIREDO TC, CANÇADO SV, VIEGAS RP, RÊGO IOP, LARA LJC, SOUSA MR \& BAIÃO NC. 2011. Qualidade de ovos comerciais submetidos a diferentes condições de armazenamento. Arq Bras Med Vet Zootec 63: 712-720.

FREITAS ER, BORGES AS, TREVISAN MTS, CUNHA AL, BRAZ NM, WATANABE PH \& NASCIMENTO GAJ. 2013. Extratos etanólicos de manga como antioxidantes na alimentação de poedeiras. Pesq Agropec Bras 48: 714-721.

GIAMPIETRO-GANECO A, SCATOLINI-SILVA AM, BORBA H, BOIAGO MM, LIMA TMA \& SOUZA PA. 2012. Estudo comparativo das características qualitativas de ovos armazenados em refrigeradores domésticos. ARS Vet 28: 100-104.

HAMILTON RMG. 1982. Methods and factors that affect the measurement of egg shell quality. Poult Sci 61: 2022-2039.

HARDER MNC, BRAZACA SGC, SAVINO VJM \& COELHO AAD. 2008. Efeito de Bixa orellana na alteração de características de ovos de galinhas. Ciênc Agrotec 32: 1232-1237.

HUBER K, QUEIROZ JH, MOREIRA AVB \& RIBEIRO SMR. 2012. Caracterização química do resíduo agroindustrial da manga ubá (Mangifera indica L.): uma perspectiva para a obtenção de antioxidantes naturais. R Bras Tecnol Agroindustr 6: 640-654.

IBGE - INSTITUTO BRASILEIRO DE GEOGRAFIA E ESTATÍSTICA. 2018. Produção Pecuária Municipal 2018. 46: 1-8. Disponivel em: < https://biblioteca.ibge.gov.br/visualizacao/ periodicos/84/ppm_2018_v46_br_informativo.pdf> Access: November 19, 2019.

JIMÉNEZ-ESCRIG A, RINCÓN M, PULIDO R \& SAURA-CALIXTO F. 2001. Guava fruit (Psidium guajava L.) as a new source of antioxidant dietary fiber. J Agric Food Chem 49: 5489-5493.

LI M, ZHAO L, LIU J, LIU AL, ZENG WS, LUO SQ \& BAI XC. 2009. Hydrogen peroxide induces $G 2$ cell cycle arrest and 
inhibits cell proliferation in osteoblasts. Anat Rec 292: 1107-1113.

LIANG H, YUF, TONG Z \& ZENG W. 2012. Lycopene effects on serum mineral elements and bone strength in rats. Molecules 17: 7093-7102.

MANTOVANI JR, CORRÊA MCM, CRUZ MCP, FERREIRA ME \& NATALE W. 2004. Uso fertilizante de resíduo da indústria processadora de goiabas. Rev Bras Frutic 26: 339-342.

MELO OS, BERGAMASCHI KB, TIVERON AP, MASSARIOLO AP, OLDONI TLC, ZANUS MC, PEREIRA GE \& ALENCAR SM. 2011. Composição fenólica e atividade antioxidante de resíduos agroindustriais. Ciênc Rur 41: 1088-1093.

MELLO HHC, XAVIER HF, OLIVEIRA MD, NOLETO R, NEVES K \& LEANDRO NSM. 2018. Effects of different level of guava extract on diet of japanese quail breeder (Coturnix coturnix japonica) on intestinal growth of neonate japanese quail. J Anim Sci 96: 331-332.

MÓRI C, GARCIA EA, PAVAN AC, PICCININ A, SCHERER MR \& PIZZOLANTE CC. 2005. Desempenho e qualidade dos ovos de codornas de quatro grupos genéticos. R Bras Zootec 34: 864-869.

MOURA AMA, FONSECA JB, RABELLO CB, TAKATA FN \& OLIVEIRA NTE. 2010. Desempenho e qualidade do ovo de codornas japonesas alimentadas com rações contendo sorgo. $R$ Bras Zootec 39: 2697-2702.

OLIVEIRA BL \& OLIVEIRA DD. 2013. Qualidade e tecnologia de ovos. Editora da Universidade Federal de Lavras, Minas Gerais, Brasil.

OLIVEIRA DS, AQUINO PP, RIBEIRO SMR, PROENÇA RPC \& PINHEIRO-SANT'ANA HMP. 2011. Vitamina C, carotenoides, fenólicos totais e atividade antioxidante de goiaba, manga e mamão procedentes da Ceasa do estado de Minas Gerais. Acta Sci Health Sci 33: 89-98.

OLIVEIRA MD, MELLO HHC, STRINGHINI JH, MASCARENHAS AG, ARNHOLD E, CONCEIÇÃO EC, MARTINS JMS \& SILVA JÚNIOR AJ. 2018. Antioxidant effect of the guava byproduct in the diet of broiler in the starter phase. R Bras Zootec 47: e20160290.

RADWAN NL, HASSAN RA, QOTA EM \& FAYEK HM. 2008. Effect of natural antioxidant on oxidative stability of eggs and productive and reproductive performance of laying hens. Int J Poult Sci 7: 134-150.

RAMALHO VC \& JORGE N. 2006. Antioxidantes utilizados em óleos, gorduras e alimentos gordurosos. Quím Nova 29: 755-760.

RORIZ CGQ. 2014. Estabilidade oxidativa de ovos e desempenho de codornas europeias (Coturnix coturnix coturnix) suplementadas com vitamina $\mathrm{C}$ e óleos de soja e de girassol. 77 p. Dissertação (Mestrado em Ciências Animais) - Faculdade de Agronomia e Medicina Veterinária da Universidade de Brasília, Brasília, Brasil. (Unpublished).

ROSTAGNO HS, ALBINO LFT, DONZELE JL, GOMES PC, OLIVEIRA RF, LOPES DC, FERREIRA AS, BARRETO SLT \& EUCLIDES RF. 2011. Tabelas brasileiras para aves e suínos: composição de alimentos e exigências nutricionais. Editora da Universidade Federal de Viçosa, Minas Gerais, Brasil.

SILVA FHA. 2004. Curso teórico-prático sobre técnicas básicas de avaliação de qualidade do ovo. Editora da Escola Superior de Agricultura "Luiz de Queiroz" da Universidade de São Paulo, São Paulo, Brasil.

SOUZA-SOARES LA \& SIEWERDT F. 2005. Aves e ovos. Editora da Universidade Federal de Pelotas, Rio Grande do Sul, Brasil.

WANG XC, WANG XH, WANG J, WANG H, ZHANG HJ, WU SC \& QI GH. 2018. Dietary tea polyphenol supplementation improved egg production performance, albumen quality, and magnum morphology of Hy-Line Brown hens during the late laying period1. J Anim Sci 96: 225-235.

VYNCKE BW. 1970. Direct determination of the thiobarbituric acid value in trichloracetic acid extracts of fish as a measure of oxidative rancidity. Fette Seifen Anstrichm 72: 1084-1087.

ZHAO X, YANG ZB, YANG WR, WANG Y, JIANG SZ AND ZHANG GG. 2011. Effects of ginger root (Zingiber officinale) on laying performance and antioxidant status of laying hens and on dietary oxidation stability. Poult Sci 90: 1720-1727.

\section{How to cite}

OLIVEIRA HF, MELLO HHC, LEANDRO NSM, MASCARENHAS AG, DA CONCEIÇÃO EC, ARNHOLD E, LAGE ME \& SOUZA MIA. 2021. Lipid stability of egg and laying performance of Japanese quail feed with extract of guava (Psidium guajava L.). An Acad Bras Cienc 93: e20191424. DOI 10.1590/0001-3765202120191424.

Manuscript received on November 19, 2019;

accepted for publication on February 19, 2020

\section{HELDER F. DE OLIVEIRA ${ }^{1}$}

https://orcid.org/0000-0003-4109-1087

HELOISA HELENA DE C. MELLO'

https://orcid.org/0000-0002-0312-7424

NADJA S.M. LEANDRO ${ }^{1}$

https://orcid.org/0000-0002-6525-9975 


\begin{abstract}
ALESSANDRA G. MASCARENHAS ${ }^{1}$
https://orcid.org/0000-0001-8333-0723

EDEMILSON C. DA CONCEIÇÃO ${ }^{2}$

https://orcid.org/0000-0003-4113-2686
\end{abstract}

\title{
EMMANUEL ARNHOLD
}

https://orcid.org/0000-0003-0922-146X

\section{MOACIR E. LAGE}

https://orcid.org/0000-0003-2060-5632

MARIA IZABEL A. SOUZA ${ }^{3}$

https://orcid.org/0000-0002-1776-0968

${ }^{1}$ Universidade Federal de Goiás, Escola de Veterinária

e Zootecnia, Avenida Esperança, s/n, Campus

Samambaia, 74690-900 Goiânia, GO, Brazil

${ }^{2}$ Universidade Federal de Goiás, Faculdade de Farmácia, Rua 240, Esquina com 5 a Avenida, s/n, Setor Leste

Universitário, 74605-170 Goiânia, GO, Brazil

${ }^{3}$ Universidade Federal de Goiás, Centro de Pesquisa

em Alimentos, Rodovia GO 462, Km 0, Campus

Samambaia, 74690-900 Goiânia, GO, Brazil

Correspondence to: Helder Freitas de Oliveira

E-mail:helder@zootecnista.com.br

\section{Author contributions}

Helder Freitas de Oliveira conceived and performed the experiments, analyzed samples, wrote the manuscript, reviewed and edited; Heloisa Helena de Carvalho Mello acted as a master's advisor of Helder Freitas de Oliveira, acquired the financial resources of this research, designed the study, supervised the project and revised the manuscript for intellectual content; Nadja Susana Mogyca Leandro acquired the financial resources of this research, supervised the project and analyzed the data; Alessandra Gimenez Mascarenhas, Edemilson Cardoso da Conceição and Moacir Evandro Lage contributed reagents, materials, and analytical tools; Emmanuel Arnhold analyzed the data and revised the manuscript for intellectual content; and Maria Izabel Amaral Souza assisted in performing the experiment, analyzed samples and contributed to analytical tools. All authors discussed the results and approved the final version of the manuscript.

\section{(cc) BY}

